\title{
Differences in healthy life expectancy between older migrants and non-migrants in three European countries over time
}

\author{
Matias Reus-Pons $^{1,2}$ (1) $\cdot$ Eva U. B. Kibele ${ }^{1}$ Fanny Janssen ${ }^{1,3}$
}

Received: 9 September 2016 / Revised: 12 January 2017 / Accepted: 13 January 2017 / Published online: 26 February 2017

(C) The Author(s) 2017. This article is published with open access at Springerlink.com

\begin{abstract}
Objectives We analysed differences in healthy life expectancy at age $50\left(\mathrm{HLE}_{50}\right)$ between migrants and nonmigrants in Belgium, the Netherlands, and England and Wales, and their trends over time between 2001 and 2011 in the latter two countries.

Methods Population, mortality and health data were derived from registers, census or surveys. $\mathrm{HLE}_{50}$ and the share of remaining healthy life years were calculated for non-migrants, western and non-western migrants by sex. We applied decomposition techniques to answer whether differences in $\mathrm{HLE}_{50}$ between origin groups and changes in $\mathrm{HLE}_{50}$ over time were attributable to either differences in mortality or health.

Results In all three countries, older (non-western) migrants could expect to live less years in good health than older non-migrants. Differences in $\mathrm{HLE}_{50}$ between migrants and non-migrants diminished over time in the Netherlands, but they increased in England and Wales. General health, rather than mortality, mainly explained (trends in) inequalities in healthy life expectancy between migrants and non-migrants.

Conclusions Interventions aimed at reducing the health and mortality inequalities between older migrants and
\end{abstract}

Matias Reus-Pons

m.reus.pons@rug.nl

1 Population Research Centre, Faculty of Spatial Sciences, University of Groningen, Groningen, The Netherlands

2 Interface Demography, Department of Sociology, Vrije Universiteit Brussel, Brussels, Belgium

3 Netherlands Interdisciplinary Demographic Institute (NIDI), The Hague, The Netherlands non-migrants should focus on prevention, and target especially non-western migrants.

Keywords Health · Mortality · Migration · Ageing · Belgium · The Netherlands · England and Wales

\section{Introduction}

While the issues of migration, ageing, and health are on the political agenda in all European countries, little attention has been paid to the health of older migrants in Europe (Rechel et al. 2011). Studying health and mortality among older migrants in Europe is important because the share of older migrants in European populations is rising steadily (Lanzieri 2011). Addressing potential health disparities between older migrants and non-migrants is consistent with the principle of equity embedded in most European health care systems and policies (Nørredam and Krasnik 2011). Knowledge about the health of older migrants will prove crucial in assessing future health care demand in culturally diverse and ageing populations (International Organization for Migration 2009), and to inform policies and interventions.

Earlier studies on migrant health and mortality produced different results. Despite their relatively low socioeconomic status, certain migrant groups have been shown to live longer than non-migrants; this phenomenon is described as the migrant mortality paradox (e.g. Razum et al. 1998; Abraído-Lanza et al. 1999). Even when an overall migrant mortality advantage is not observed, migrants may still have a mortality advantage compared with non-migrants in a similar socio-economic position (Riosmena et al. 2013). However, living longer does not necessarily imply living in good health (Uitenbroek and 
Verhoeff 2002). Indeed, migrants tend to have worse selfrated health than non-migrants (Nielsen and Krasnik 2010).

The few existing studies that focused on this issue found that health and mortality differences between migrants and non-migrants persist with age. At older ages, migrants tend to have lower mortality than non-migrants (Markides and Eschbach 2005; Carnein et al. 2014; Lariscy et al. 2015; Reus-Pons et al. 2016), but also worse self-rated health, worse functioning, and higher rates of disability and depression (Solé-Auró and Crimmins 2008; Lanari and Bussini 2012; Carnein et al. 2014). While previous studies showed that migrants tend to experience a steeper decline in health with age and length of stay (Ronellenfitsch and Razum 2004; Lanari and Bussini 2012), this was not the case for mortality (Markides and Eschbach 2005; ReusPons et al. 2016).

To address the questions surrounding the health and mortality differences between migrants and non-migrants, the combined study of health and mortality is essential. Healthy life expectancy (HLE) is a powerful tool for tackling these issues, and can be used to make cross-country comparisons. However, earlier cross-country comparisons of HLE did not break down the population by migrant origin (Jagger et al. 2008, 2011; Wohland et al. 2014; Fouweather et al. 2015); and to our knowledge, only one existing study has applied HLE in studying health and mortality differences between older migrants and non-migrants in a single country (Carnein et al. 2014).

Moreover, as health inequalities between countries (Fouweather et al. 2015) and between socio-economic groups (Hu et al. 2016) are growing, evaluating the trends in the HLE gaps between older migrants and non-migrants could provide us with answers to the question of whether health inequalities between migrants and non-migrants (subsequently referred to as migrant health inequalities) are also increasing or, in contrast, decreasing. Up to now, the only studies on this issue that incorporated a time dimension did not break down the population by migrant origin (Wohland et al. 2014; Fouweather et al. 2015; Hu et al. 2016).

Our aim is to compare the differences in HLE between older migrants and non-migrants in three European countries: Belgium, the Netherlands, and England and Wales; and to assess their trends over time in the latter two countries.

We selected these three countries because they have similar life expectancies at birth, similar migration histories, and reliable data. The vast majority of the older migrants living in Europe today are first-generation migrants who arrived before the early 1970s as guest workers, from neighbouring countries, or from former colonies (Lanzieri 2011). However, the largest country of origin groups differ in each of these three countries due to different colonial ties, and to the fact that labour migrants originated from different areas (Mediterranean countries in Belgium and the Netherlands, and New Commonwealth countries in England and Wales).

\section{Methods}

\section{Data}

In this study, we focus on first-generation migrants and non-migrants aged 50 years and over in Belgium (2001), the Netherlands (2001 and 2011), and England and Wales (2001 and 2011). Migrants were defined as those born in a country other than their current country of residence. According to their country of origin, migrants were then subdivided into western (origin in a European country, USA, Canada, Australia, New Zealand, or Japan) and nonwestern (CBS 2016a). In England and Wales, individuals born in other parts of the UK were also classified as western migrants.

To calculate healthy life expectancy at age 50 $\left(\mathrm{HLE}_{50}\right)$-i.e. the expected number of remaining years spent in good health-we relied on yearly population, mortality, and health data by sex, migrant origin, and five-year age groups $(50-54, \ldots, 85+)$, which were derived from registers, censuses, and surveys we obtained from Statistics Belgium, Statistics Netherlands, and the Office for National Statistics (Table 1).

We reclassified self-rated health from its original five categories (very good, good, fair, bad, very bad) to a binary variable, distinguishing between good (good to very good) and poor health (very bad to fair). In the 2001 census for England and Wales only, self-rated health was originally classified in three categories instead (good, fairly good, not good). To allow for comparability, we applied adjustment factors developed by ONS (Smith and White 2009).

The Dutch survey data were weighted by Statistics Netherlands based on age, sex, and other demographic characteristics, including migrant background (CBS 2016b, c) to represent the national population. In Belgium, data on selfrated health was missing for around 5\% of the non-migrant population and around $10 \%$ of the migrant population; we therefore weighted the Belgian self-rated health data using simple ratio weights (Fawcett et al. 2002) based on sex, age, migrant background, education, and urbanity of the area of residence.

In 2001, the proportion of migrants who were aged 50 and over was $11.4 \%$ in England and Wales, $11.1 \%$ in Belgium and $7.6 \%$ in the Netherlands (Table 2). The majority of older migrants in all three countries were of western origin. However, in 2011 the majority of male migrants in the Netherlands and in England and Wales were of nonwestern origin. Individuals born in other parts of the UK 
Table 1 Data sources by country and year

\begin{tabular}{|c|c|c|c|c|c|c|c|}
\hline \multirow[t]{2}{*}{ Country } & \multirow[t]{2}{*}{ Year } & \multicolumn{2}{|c|}{ Population } & \multicolumn{2}{|l|}{ Deaths } & \multicolumn{2}{|l|}{ Self-rated health } \\
\hline & & Source & Year & Source & Year & Source & Year \\
\hline Belgium & 2001 & Census & 2001 & Register & 2002 & Census $^{\mathrm{a}}$ & 2001 \\
\hline The Netherlands & $\begin{array}{l}2001 \\
2011\end{array}$ & Register & $\begin{array}{l}2001 \\
2011\end{array}$ & Register & $\begin{array}{l}2001 \\
2011\end{array}$ & $\begin{array}{l}\text { Survey data: Permanent Survey on the Liv- } \\
\text { ing Situation (POLS) and Health Survey }\end{array}$ & $\begin{array}{l}2001^{\mathrm{c}} \\
2011^{\mathrm{c}}\end{array}$ \\
\hline England and Wales & $\begin{array}{l}2001 \\
2011\end{array}$ & Census & $\begin{array}{l}2001 \\
2011\end{array}$ & Death certificates & $\begin{array}{l}2001 \\
2011\end{array}$ & Census & $\begin{array}{l}2001 \\
2011\end{array}$ \\
\hline
\end{tabular}

${ }^{a}$ Data from the Belgian Health Interview Survey not used due to the large amount of missing data

${ }^{\mathrm{b}}$ The Health Survey substituted the part on health of the POLS after 2009, but no major changes were made to the question and answer choices regarding self-rated health

${ }^{c}$ Data from the different surveys in the Netherlands were aggregated around the years 2001 (POLS 1999-2003) and 2011 (POLS 2009 , Health Survey 2010-2013) to increase the sample size

Table 2 Population aged 50 and over $\left(N_{50+}\right)$, and sample size in the health survey $\left(n_{50+}\right)$ by sex, migrant origin, and country in Belgium (2001), the Netherlands (2001-2011), and England and Wales (20012011)

\begin{tabular}{|c|c|c|c|c|c|c|c|}
\hline & \multirow{3}{*}{$\begin{array}{l}\text { Belgium } \\
2001 \\
N_{50+}\end{array}$} & \multicolumn{4}{|c|}{ The Netherlands } & \multicolumn{2}{|c|}{ England and Wales } \\
\hline & & \multicolumn{2}{|l|}{2001} & \multicolumn{2}{|l|}{2011} & \multirow{2}{*}{$\begin{array}{l}2001 \\
N_{50+}\end{array}$} & \multirow{2}{*}{$\begin{array}{l}2011 \\
N_{50+}\end{array}$} \\
\hline & & $N_{50+}$ & $n_{50+}$ & $N_{50+}$ & $n_{50+}$ & & \\
\hline \multicolumn{8}{|l|}{ Males } \\
\hline Total & $1,587,355$ & $2,306,401$ & 24,637 & $2,842,126$ & 12,369 & $7,991,367$ & $9,114,457$ \\
\hline Non-migrants & $1,407,572$ & $2,129,003$ & 23,132 & $2,584,237$ & 11,581 & $7,075,198$ & $7,904,468$ \\
\hline Migrants & 179,783 & 177,398 & 1505 & 257,889 & 788 & 916,169 & $1,209,989$ \\
\hline Western migrants & 137,501 & 98,962 & 1004 & 114,573 & 426 & 542,579 & 598,162 \\
\hline $\begin{array}{l}\text { Non-western } \\
\text { migrants }\end{array}$ & 42,282 & 78,436 & 501 & 143,316 & 362 & 373,590 & 611,827 \\
\hline \multicolumn{8}{|l|}{ Females } \\
\hline Total & $1,915,005$ & $2,667,522$ & 26,317 & $3,143,038$ & 13,340 & $9,419,478$ & $10,271,387$ \\
\hline Non-migrants & $1,705,610$ & $2,467,807$ & 24,671 & $2,854,149$ & 12,476 & $8,344,831$ & $8,853,063$ \\
\hline Migrants & 209,395 & 199,715 & 1646 & 288,889 & 864 & $1,074,647$ & $1,418,324$ \\
\hline Western migrants & 173,509 & 128,682 & 1222 & 144,625 & 511 & 674,695 & 742,971 \\
\hline $\begin{array}{l}\text { Non-western } \\
\text { migrants }\end{array}$ & 35,886 & 71,033 & 424 & 144,264 & 353 & 399,952 & 675,353 \\
\hline
\end{tabular}

Data sources: Statistics Belgium, Statistics Netherlands, and Office for National Statistics@ Crown Copyright 2015 constituted 23.9\% (2001) and 19.5\% (2011) of the migrant population in England and Wales.

\section{Methods}

$\mathrm{HLE}_{50}$ was calculated using the Sullivan method (1971). To test whether there were differences in $\mathrm{HLE}_{50}$ between older migrants and non-migrants, we calculated $95 \%$ confidence intervals (Jagger et al. 2006). Additionally, to provide a full picture, we estimated the proportion of the expected remaining years of life spent in good health $\left(\mathrm{HLE}_{50} / \mathrm{LE}_{50}\right)$, where $\mathrm{LE}_{50}$ stands for life expectancy at age 50, calculated using standard life table techniques (Preston et al. 2000).

Trends in $\mathrm{HLE}_{50}$ by migrant background over time were assessed by comparing both changes in $\mathrm{HLE}_{50}$ and in
$\mathrm{HLE}_{50} / \mathrm{LE}_{50}$ between 2001 and 2011. Decomposition techniques were applied to identify to what extent the differences in $\mathrm{HLE}_{50}$ between groups and the changes in $\mathrm{HLE}_{50}$ over time were attributable to differences in mortality, or to differences in self-rated health (Nusselder and Looman 2004).

\section{Results}

\section{Inequalities in $\mathrm{HLE}_{50}$ between migrants and non-migrants}

Regardless of the fact that migrants' $\mathrm{LE}_{50}$ was higher than that of non-migrants in Belgium (2001), and in the 
Table 3 Life expectancy $\left(\mathrm{LE}_{50}\right)$ and healthy life expectancy $\left(\mathrm{HLE}_{50}\right)$ at age 50, and share of years spent in good health after age $50\left(\mathrm{HLE}_{50} /\right.$ $\mathrm{LE}_{50}$ ) by sex and migrant origin in Belgium (2001), the Netherlands (2001-2011), and England and Wales (2001-2011)

\begin{tabular}{|c|c|c|c|c|c|c|c|c|c|}
\hline & \multicolumn{3}{|c|}{ Belgium (2001) } & \multicolumn{3}{|c|}{ The Netherlands (2001) } & \multicolumn{3}{|c|}{ England and Wales (2001) } \\
\hline & $\mathrm{LE}_{50}$ (years) & $\begin{array}{l}\mathrm{HLE}_{50} \\
(95 \% \mathrm{CI}) \\
\text { (years) }\end{array}$ & $\mathrm{HLE}_{50} / \mathrm{LE}_{50}$ & $\mathrm{LE}_{50}$ (years) & $\begin{array}{l}\mathrm{HLE}_{50} \\
(95 \% \mathrm{CI}) \\
\text { (years) }\end{array}$ & $\mathrm{HLE}_{50} / \mathrm{LE}_{50}$ & $\mathrm{LE}_{50}$ (years) & $\begin{array}{l}\mathrm{HLE}_{50} \\
(95 \% \mathrm{CI}) \\
\text { (years) }\end{array}$ & $\mathrm{HLE}_{50} / \mathrm{LE}_{50}$ \\
\hline \multicolumn{10}{|l|}{ Males } \\
\hline Total & 27.87 & $\begin{array}{c}14.48(14.44 \\
14.52)\end{array}$ & 0.519 & 28.05 & $\begin{array}{l}18.62(18.40 \\
18.84)\end{array}$ & 0.664 & 28.54 & $\begin{array}{l}18.47(18.46 \\
18.48)\end{array}$ & 0.647 \\
\hline $\begin{array}{l}\text { Non- } \\
\text { migrants }\end{array}$ & 27.79 & $\begin{array}{l}14.71(14.66 \\
14.75)\end{array}$ & 0.529 & 28.15 & $\begin{array}{l}18.92(18.69 \\
19.14)\end{array}$ & 0.672 & 28.66 & $\begin{array}{c}18.59(18.58 \\
18.60)\end{array}$ & 0.649 \\
\hline Migrants & 28.26 & $\begin{array}{l}12.52(12.41 \\
12.62)\end{array}$ & 0.443 & 26.77 & $\begin{array}{c}14.88(14.03 \\
15.72)\end{array}$ & 0.556 & 27.52 & $\begin{array}{c}17.53(17.50 \\
17.55)\end{array}$ & 0.637 \\
\hline $\begin{array}{l}\text { Western } \\
\text { migrants }\end{array}$ & 28.14 & $\begin{array}{l}12.61(12.49 \\
12.73)\end{array}$ & 0.448 & 26.60 & $\begin{array}{l}17.12(16.16 \\
18.07)\end{array}$ & 0.644 & 27.06 & $\begin{array}{c}17.61(17.58, \\
17.65)\end{array}$ & 0.651 \\
\hline $\begin{array}{l}\text { Non- } \\
\text { western } \\
\text { migrants }\end{array}$ & 29.52 & $\begin{array}{l}12.32(12.03, \\
12.60)\end{array}$ & 0.417 & 27.78 & $\begin{array}{c}10.57(8.72 \\
12.42)\end{array}$ & 0.381 & 28.26 & $\begin{array}{c}17.43(17.38 \\
17.48)\end{array}$ & 0.617 \\
\hline \multicolumn{10}{|l|}{ Females } \\
\hline Total & 32.84 & $\begin{array}{c}15.29(15.25 \\
15.32)\end{array}$ & 0.465 & 32.47 & $\begin{array}{l}19.43(19.19 \\
19.68)\end{array}$ & 0.599 & 32.32 & $\begin{array}{l}19.82(19.81 \\
19.83)\end{array}$ & 0.613 \\
\hline $\begin{array}{l}\text { Non- } \\
\text { migrants }\end{array}$ & 32.82 & $\begin{array}{l}15.61(15.57, \\
15.64)\end{array}$ & 0.475 & 32.58 & $\begin{array}{l}19.76(19.51 \\
20.02)\end{array}$ & 0.607 & 32.39 & $\begin{array}{c}19.94(19.93 \\
19.95)\end{array}$ & 0.616 \\
\hline Migrants & 33.16 & $\begin{array}{l}12.76(12.66 \\
12.85)\end{array}$ & 0.385 & 31.01 & $\begin{array}{c}15.23(14.31 \\
16.15)\end{array}$ & 0.491 & 31.82 & $\begin{array}{c}19.02(18.99 \\
19.05)\end{array}$ & 0.598 \\
\hline $\begin{array}{l}\text { Western } \\
\text { migrants }\end{array}$ & 33.31 & $\begin{array}{l}13.16(13.05 \\
13.26)\end{array}$ & 0.395 & 30.91 & $\begin{array}{l}17.12(16.06 \\
18.18)\end{array}$ & 0.554 & 31.68 & $\begin{array}{l}19.78(19.74 \\
19.82)\end{array}$ & 0.624 \\
\hline \multirow{3}{*}{$\begin{array}{l}\text { Non- } \\
\text { western } \\
\text { migrants }\end{array}$} & 33.55 & $\begin{array}{c}11.51(11.19, \\
11.82)\end{array}$ & 0.343 & 32.13 & $\begin{array}{c}11.60(9.67, \\
13.53)\end{array}$ & 0.361 & 32.13 & $\begin{array}{c}17.83(17.77 \\
17.88)\end{array}$ & 0.555 \\
\hline & \multicolumn{3}{|c|}{ Belgium (2011) } & \multicolumn{3}{|c|}{ The Netherlands (2011) } & \multicolumn{3}{|c|}{ England and Wales (2011) } \\
\hline & $\mathrm{LE}_{50}$ (years) & $\begin{array}{l}\mathrm{HLE}_{50} \\
(95 \% \mathrm{CI}) \\
\text { (years) }\end{array}$ & $\mathrm{HLE}_{50} / \mathrm{LE}_{50}$ & $\mathrm{LE}_{50}$ (years) & $\begin{array}{l}\mathrm{HLE}_{50} \\
(95 \% \mathrm{CI}) \\
\text { (years) }\end{array}$ & $\mathrm{HLE}_{50} / \mathrm{LE}_{50}$ & $\mathrm{LE}_{50}$ (years) & $\begin{array}{l}\mathrm{HLE}_{50} \\
(95 \% \mathrm{CI}) \\
\text { (years) }\end{array}$ & $\mathrm{HLE}_{50} / \mathrm{LE}_{50}$ \\
\hline \multicolumn{10}{|l|}{ Males } \\
\hline Total & - & - & - & 30.87 & $\begin{array}{l}20.83(20.55 \\
21.10)\end{array}$ & 0.675 & 31.29 & $\begin{array}{l}18.71(18.70 \\
18.72)\end{array}$ & 0.598 \\
\hline $\begin{array}{l}\text { Non- } \\
\text { migrants }\end{array}$ & - & - & - & 30.95 & $\begin{array}{l}21.09(20.80 \\
21.37)\end{array}$ & 0.681 & 31.32 & $\begin{array}{l}18.82(18.81 \\
18.83)\end{array}$ & 0.601 \\
\hline Migrants & - & - & - & 29.88 & $\begin{array}{c}17.18(15.99 \\
18.37)\end{array}$ & 0.575 & 31.01 & $\begin{array}{c}17.98(17.95 \\
18.01)\end{array}$ & 0.580 \\
\hline $\begin{array}{l}\text { Western } \\
\text { migrants }\end{array}$ & - & - & - & 29.38 & $\begin{array}{l}18.79(17.36 \\
20.22)\end{array}$ & 0.640 & 30.04 & $\begin{array}{l}18.26(18.22 \\
18.29)\end{array}$ & 0.608 \\
\hline $\begin{array}{l}\text { Non- } \\
\text { western } \\
\text { migrants }\end{array}$ & - & - & - & 31.13 & $\begin{array}{l}15.20(12.68 \\
17.72)\end{array}$ & 0.488 & 32.31 & $\begin{array}{c}17.72(17.68 \\
17.77)\end{array}$ & 0.548 \\
\hline \multicolumn{10}{|l|}{ Females } \\
\hline Total & - & - & - & 34.31 & $\begin{array}{l}20.68(20.37 \\
20.99)\end{array}$ & 0.603 & 34.50 & $\begin{array}{l}19.67(19.66 \\
19.68)\end{array}$ & 0.570 \\
\hline $\begin{array}{l}\text { Non- } \\
\text { migrants }\end{array}$ & - & - & - & 34.36 & $\begin{array}{l}20.95(20.63 \\
21.27)\end{array}$ & 0.610 & 34.47 & $\begin{array}{c}19.89(19.87 \\
19.90)\end{array}$ & 0.577 \\
\hline Migrants & - & - & - & 33.49 & $\begin{array}{c}16.77(15.47, \\
18.06)\end{array}$ & 0.501 & 34.84 & $\begin{array}{c}18.41(18.39 \\
18.44)\end{array}$ & 0.528 \\
\hline $\begin{array}{l}\text { Western } \\
\text { migrants }\end{array}$ & - & - & - & 33.05 & $\begin{array}{c}18.43(16.94 \\
19.92)\end{array}$ & 0.558 & 34.33 & $\begin{array}{l}20.02(19.98 \\
20.05)\end{array}$ & 0.583 \\
\hline
\end{tabular}


Table 3 (continued)

\begin{tabular}{|c|c|c|c|c|c|c|c|c|c|}
\hline & \multicolumn{3}{|c|}{ Belgium (2011) } & \multicolumn{3}{|c|}{ The Netherlands (2011) } & \multicolumn{3}{|c|}{ England and Wales (2011) } \\
\hline & $\mathrm{LE}_{50}$ (years) & $\begin{array}{l}\mathrm{HLE}_{50} \\
(95 \% \mathrm{CI}) \\
\text { (years) }\end{array}$ & $\mathrm{HLE}_{50} / \mathrm{LE}_{50}$ & $\mathrm{LE}_{50}$ (years) & $\begin{array}{l}\mathrm{HLE}_{50} \\
(95 \% \mathrm{CI}) \\
\text { (years) }\end{array}$ & $\mathrm{HLE}_{50} / \mathrm{LE}_{50}$ & $\mathrm{LE}_{50}$ (years) & $\begin{array}{l}\mathrm{HLE}_{50} \\
(95 \% \mathrm{CI}) \\
\text { (years) }\end{array}$ & $\mathrm{HLE}_{50} / \mathrm{LE}_{50}$ \\
\hline $\begin{array}{l}\text { Non- } \\
\text { western } \\
\text { migrants }\end{array}$ & - & - & - & 34.73 & $\begin{array}{c}14.49(11.44 \\
17.54)\end{array}$ & 0.417 & 35.71 & $\begin{array}{c}16.53(16.48 \\
16.58)\end{array}$ & 0.463 \\
\hline
\end{tabular}

Data sources: Statistics Belgium, Statistics Netherlands, and Office for National Statistics@ Crown Copyright 2015

Netherlands and England and Wales (2011), HLE ${ }_{50}$ was significantly lower for migrants, especially those of nonwestern origin, than for non-migrants in all three countries and in both 2001 and 2011 (Table 3). The largest migrant inequality gap in $\mathrm{HLE}_{50}$ was found in the Netherlands. The estimated proportion of the expected remaining years of life spent in good health $\left(\mathrm{HLE}_{50} / \mathrm{LE}_{50}\right)$ followed a similar pattern. In England and Wales only, western migrants could expect to live a larger share of their remaining life in good health than non-migrants in both 2001 and 2011.

Migrant inequalities in $\mathrm{HLE}_{50}$ were mainly attributable to differences in self-rated health (Table 4). Mortality often contributed in the opposite direction; for example, for Belgian males in 2001, the negative contribution of mortality was due to the lower overall mortality among migrants. In contrast to the general trend, migrant inequalities in $\mathrm{HLE}_{50}$ in England and Wales were mainly explained by differences in mortality, since western migrants, albeit experiencing higher mortality, could expect to live a larger share of their remaining life in good health than non-migrants.

\section{Trends in $\mathrm{HLE}_{50}$ between 2001 and 2011}

Between 2001 and 2011, the gap in $\mathrm{HLE}_{50}$ between (nonwestern) migrants and non-migrants diminished in the Netherlands and among males in England and Wales, but widened among females in England and Wales (Table 3). However, if we look at the change in $\mathrm{HLE}_{50} / \mathrm{LE}_{50}$, we see that migrant health inequalities increased for both sexes in England and Wales. Although non-western migrants continued to be the group with the lowest $\mathrm{HLE}_{50}$ and $\mathrm{HLE}_{50}$ / $\mathrm{LE}_{50}$ in the Netherlands, the gap with respect to nonmigrants and western migrants decreased slightly.

In general, we find that increases in $\mathrm{HLE}_{50}$ were mainly attributable to decreases in mortality, and were driven by improvements in self-rated health only among non-western migrants in the Netherlands (Table 5). Improvements in HLE did not keep pace with improvements in LE for most groups. The decreases in $\mathrm{HLE}_{50}$ among females in England and Wales were driven by declines in the prevalence of good self-rated health.

\section{Discussion}

\section{Summary of the results}

In all three countries studied, migrants aged 50 years and older could expect to live fewer years in good self-rated health than non-migrants. Non-western migrants had the lowest $\mathrm{HLE}_{50}$, especially in the Netherlands. The differences in $\mathrm{HLE}_{50}$ between (non-western) migrants and nonmigrants were mainly determined by differences in selfrated health. Between 2001 and 2011, migrant inequalities in both $\mathrm{HLE}_{50}$ and $\mathrm{HLE}_{50} / \mathrm{LE}_{50}$ were reduced in the Netherlands, mainly driven by improvements in self-rated health among non-western migrants. While migrant inequalities in $\mathrm{HLE}_{50}$ diminished among males in England and Wales, migrant inequalities in $\mathrm{HLE}_{50} / \mathrm{LE}_{50}$ increased for both sexes.

\section{Evaluation of the data and methods}

The results of our analysis are based on highly reliable population and health data. Nevertheless, several limitations of the study should be noted. Although self-rated health has been reported to be reliable for the total population, concerns have been raised about its use when comparing different ethnic groups (e.g. Chandola and Jenkinson 2000). Seo et al. (2014), however, found that variations in the response patterns do not differ according to origin, but to the responding language instead. In our study, census and surveys were provided in the national languages only, which helps reducing the potential variability in the response pattern between migrants and non-migrants. Furthermore, studies of older migrants that relied on more objective health indicators, such as depression, functioning, or disability (Solé-Auró and Crimmins 2008; Lanari and 
Table 4 Decomposed differences in healthy life expectancy at age 50 (HLE $\left.{ }_{50}\right)$ between migrant origin groups by sex in Belgium (2001), the Netherlands (2001-2011), and England and Wales (2001-2011)

\begin{tabular}{ll}
2001 & \\
\hline $\begin{array}{l}\text { Difference } \\
\text { in HLE } \\
\text { (years) }\end{array}$ & Difference due to \\
\cline { 2 - 2 } & Mortality (\%) $\begin{array}{l}\text { Self-rated } \\
\text { health }\end{array}$
\end{tabular}

\section{1}

\begin{tabular}{|c|c|}
\hline Difference & Difference due to \\
\hline (years) & $\begin{array}{cc}\text { Mortality (\%) } & \begin{array}{l}\text { Self-rated } \\
\text { health (\%) }\end{array}\end{array}$ \\
\hline
\end{tabular}

(\%)
Difference between non-migrants and migrants

Males

Belgium

The Netherlands

England and Wales

Females

Belgium

The Netherlands

England and Wales

Difference between non-migrants and western migrants

Males

Belgium

The Netherlands

England and Wales

Females

Belgium

The Netherlands

England and Wales

Difference between non-migrants and non-western migrants

Males

Belgium

The Netherlands

England and Wales

Females

Belgium

The Netherlands

England and Wales

Difference between western migrants and non-western migrants

Males

Belgium

The Netherlands

England and Wales

Females

Belgium

The Netherlands

England and Wales

$\begin{array}{lrrlll}2.19^{*} & -9.6 & 109.6 & - & - & - \\ 4.04^{*} & 19.1 & 80.9 & 3.90^{*} & 15.9 & 84.1 \\ 1.06^{*} & 61.2 & 38.8 & 0.84^{*} & 18.7 & 81.3 \\ & & & & & \\ 2.85^{*} & -3.8 & 103.8 & - & - & - \\ 4.53^{*} & 17.7 & 82.3 & 4.19^{*} & 9.3 & 90.7 \\ 0.93^{*} & 29.3 & 70.7 & 1.47^{*} & -8.7 & 108.7\end{array}$

$2.10 *$

$-8.1$

49.6

94.1

$\begin{aligned} 108.1 & - \\ 50.4 & 2.29^{*} \\ 5.9 & 0.56^{*}\end{aligned}$

41.1

$-$

$0.97 *$

$-6.7$

$2.45^{*}$

32.8

106.7

$67.2 \quad 2.52 *$

$2.52^{*}$

24.6

75.4

$0.16^{*}$

214.7

$-114.7-0.13^{*}$

$-63.2$

163.2

$\begin{array}{rrrlll}2.39^{*} & -21.5 & 121.5 & - & - & - \\ 8.34^{*} & 1.9 & 98.1 & 5.88^{*} & -1.5 & 101.5 \\ 1.15^{*} & 20.9 & 79.1 & 1.10^{*} & -32.5 & 132.5 \\ & & & & & \\ 4.10^{*} & -3.1 & 103.1 & - & - & - \\ 8.16^{*} & 2.6 & 97.4 & 6.46^{*} & -3.3 & 103.3 \\ 2.12^{*} & 5.4 & 94.6 & 3.36^{*} & -11.9 & 111.9\end{array}$

Data sources: Statistics Belgium, Statistics Netherlands, and Office for National Statistics@ Crown Copyright 2015

*Statistically significant $(p<0.05)$

Bussini 2012; Carnein et al. 2014), found similar results, i.e. migrants are less healthy than non-migrants.
Our data might also suffer from comparability issues between countries and over time. Even when the same question format is used, self-rated health outcomes 
Table 5 Decomposed change in healthy life expectancy at age $50\left(\mathrm{HLE}_{50}\right)$ between 2001 and 2011 by sex and migrant origin in the Netherlands and in England and Wales (2001-2011)

\begin{tabular}{|c|c|c|c|c|c|c|}
\hline & \multicolumn{3}{|c|}{ The Netherlands } & \multicolumn{3}{|c|}{ England and Wales } \\
\hline & \multirow{2}{*}{$\begin{array}{l}\text { Difference in } \\
\text { HLE }_{50} \text { (years) }\end{array}$} & \multicolumn{2}{|c|}{ Difference due to } & \multirow{2}{*}{$\begin{array}{l}\text { Difference in } \\
\text { HLE }_{50} \text { (years) }\end{array}$} & \multicolumn{2}{|c|}{ Difference due to } \\
\hline & & Mortality (\%) & $\begin{array}{l}\text { Self-rated } \\
\text { health }(\%)\end{array}$ & & Mortality (\%) & $\begin{array}{l}\text { Self-rated } \\
\text { health } \\
(\%)\end{array}$ \\
\hline \multicolumn{7}{|l|}{ Males } \\
\hline Total & $2.21 *$ & 75.4 & 24.6 & $0.25 *$ & 533.0 & -433.0 \\
\hline Non-migrants & $2.17 *$ & 76.7 & 23.3 & $0.23 *$ & 547.2 & -447.2 \\
\hline Migrants & $2.30 *$ & 72.6 & 27.4 & $0.45^{*}$ & 371.5 & -271.5 \\
\hline Western migrants & 1.67 & 95.0 & 5.0 & $0.64 *$ & 232.4 & -132.4 \\
\hline Non-western migrants & $4.63 *$ & 30.1 & 69.9 & $0.29 *$ & 636.6 & -536.6 \\
\hline \multicolumn{7}{|l|}{ Females } \\
\hline Total & $1.25 *$ & 71.3 & 28.7 & $-0.15^{*}$ & -609.9 & 709.9 \\
\hline Non-migrants & $1.19 *$ & 71.6 & 28.4 & $-0.06^{*}$ & -1502.9 & 1602.9 \\
\hline Migrants & 1.54 & 80.5 & 19.5 & $-0.60 *$ & -205.9 & 305.9 \\
\hline Western migrants & 1.31 & 83.3 & 16.7 & $0.24 *$ & 473.3 & -373.3 \\
\hline Non-western migrants & 2.89 & 41.8 & 58.2 & $-1.30 *$ & -103.7 & 203.7 \\
\hline
\end{tabular}

Data sources: Statistics Netherlands, and Office for National Statistics@ Crown Copyright 2015

*Statistically significant $(p<0.05)$

reported by the older population in surveys may vary due to differences in survey response, sample size, and survey mode (Croezen et al. 2016). For instance, the exclusion of people living in institutions from the sample frame in the Netherlands might have led to an overestimation of $\mathrm{HLE}_{50}$, as a high share of the population-and especially non-migrants and western migrants-live in institutions after age 80. In England and Wales, the self-rated health data in the 2001 census were originally classified in three response categories instead of five. Although we applied adjustment factors to ensure comparability across countries and over time, the adjustment factors are less reliable among the oldest old (Smith and White 2009). To assess the influence of these data limitations on our $\mathrm{HLE}_{50}$ estimations, we performed a sensitivity analysis excluding the population aged 80 and over. We therefore calculated the temporary healthy life expectancy between ages 50 and 79 (THLE $_{50-79}$ ) by applying the Sullivan method (1971) to the temporary life expectancy (Arriaga 1984) between ages 50 and 79 (results not shown). The most remarkable difference found in both analyses was that the THLE $_{50-79}$ for females in England and Wales increased between 2001 and 2011, while the $\mathrm{HLE}_{50}$ decreased. The THLE $50-79$ gap between non-migrants and non-western migrants in the Netherlands was also smaller than the $\mathrm{HLE}_{50}$ gap; thus supporting the assumption that the large migrant health inequalities in the Netherlands were, at least partially, attributable to the exclusion of the institutionalized population from the sample frame.
Nevertheless, similar patterns were found in $\mathrm{HLE}_{50}$ and THLE $_{50-79}$ when comparing migrants and non-migrants across countries, and when comparing trends over time. In light of the outcomes of these additional THLE $_{50-79}$ analyses, we may not be able to identify with certainty the countries in which older migrants have a longer or a shorter $\mathrm{HLE}_{50}$. However, we can conclude that older migrants, especially those of non-western origin, can expect to live fewer years in good self-rated health than older non-migrants, in all three countries studied. These findings are consistent across the three countries, and with the results of previous studies in Europe (SoléAuró and Crimmins 2008; Lanari and Bussini 2012). In a similar vein, while we may be unable to state with certainty that $\mathrm{HLE}_{50}$ among females in England and Wales decreased over time, we can assert that the migrant health gaps in $\mathrm{HLE}_{50}$ and $\mathrm{HLE}_{50} / \mathrm{LE}_{50}$ in England and Wales increased.

Finally, we classified residents of England and Wales who were born in other parts of the UK as western migrants. Since the migration trajectories of these internal migrants are likely to differ considerably from those of international migrants, we performed a sensitivity analysis in which we excluded Scottish and Northern Irish individuals from the dataset. This did not substantially alter the results, and the conclusions drawn from the comparison of $\mathrm{HLE}_{50}$ and $\mathrm{HLE}_{50} / \mathrm{LE}_{50}$ between groups and over time remained the same (results not shown). 


\section{Interpretation of the results}

Using HLE as an indicator that combines mortality and health, our results consistently show that the HLE of older migrants, especially those of non-western origin, was lower than that of non-migrants. In most cases, these differences were mainly attributable to differences in selfrated health. Thus, our results are consistent with those of previous studies that merely used health as an outcome measure. These studies showed that compared to their non-migrant counterparts, older migrants in Europe have worse self-rated health, and more chronic conditions, limitations, and depression (Solé-Auró and Crimmins 2008; Lanari and Bussini 2012; Carnein et al. 2014). Poor health among migrants has often been explained by a range of individual and contextual factors, including economic difficulties, poor housing and working conditions, limited access to health care, cultural and language barriers, and social exclusion (Gushulak et al. 2010). The health-related lifestyles migrants adopt over their life course can affect their health at older ages; in addition, older migrants may be more prone than non-migrants to contracting diseases related to early life deprivation in their country of origin (Razum and Twardella 2002). The results also indicate, however, that the contribution of mortality to differences in $\mathrm{HLE}_{50}$ between migrants and non-migrants was often small, and in certain cases, even contributed in the opposite direction. These findings are in line with the general migrant mortality paradox (Razum et al. 1998; AbraídoLanza et al. 1999), or at least with weaker versions of it (Riosmena et al. 2013). The decomposition results illustrate how health and mortality do not necessarily follow a similar pattern, and hence the added value of using a combined measure (HLE) to study health and mortality disparities between migrants and non-migrants.

In England and Wales, the migrant $\mathrm{HLE}_{50}$ inequalities decreased among males, but increased among females. However, the migrant $\mathrm{HLE}_{50} / \mathrm{LE}_{50}$ inequality gap in England and Wales increased for both sexes. The discrepancy among males can be attributed to the failure of improvements in HLE to keep pace with improvements in LE (morbidity expansion), especially among non-western migrants. Previous studies have also found that contemporary improvements in HLE in Europe tend to be slower than improvements in LE (Harper 2015). The increase in migrant HLE inequalities observed in England and Wales follows more general patterns, such as the increase in differences in HLE between local areas in Great Britain (Wohland et al. 2014) or between European countries (Fouweather et al. 2015). Economic hardship due to the economic crisis may explain why self-rated health did not improve over time (Clair et al. 2016), especially among (non-western) migrants, who are especially vulnerable to economic downturns given their fragile socio-economic position (International Organization for Migration 2010).

Our results also show, however, that migrant inequalities in both $\mathrm{HLE}_{50}$ and in $\mathrm{HLE}_{50} / \mathrm{LE}_{50}$ in the Netherlands declined over time. In fact, only among non-western migrants in the Netherlands, improvements in $\mathrm{HLE}_{50}$ over time were mainly driven by improvements in self-rated health, rather than by decreases in mortality. Although non-western migrants were the only group in the Netherlands for whom improvements in HLE were markedly faster than improvements in LE, there was also no morbidity expansion among western migrants or nonmigrants either. A potential explanation for this finding is that unlike in most European countries, public spending on health in the Netherlands after the 2008 crisis was increased, and measures aimed at reducing pressure on highly congested medical services were implemented (Mladovsky et al. 2012).

\section{Overall conclusion}

Our analysis of health and mortality differences between older migrants and non-migrants across three countries over a 10-year period has generated some important new findings. Self-rated health, rather than mortality, seems to be the key explanatory factor beyond migrant inequalities in HLE, and their reduction over time. Interventions to reduce the health and mortality inequalities between older migrants and non-migrants should focus mainly on prevention rather than (palliative) treatment, and target the most disadvantaged groups, including non-western migrants.

Acknowledgements All authors received funding from the University of Groningen. We would like to express our gratitude to Didier Willaert (Interface Demography, Vrije Universiteit Brussel) and Statistics Belgium for supplying the Belgian data; to the Central Bureau of Statistics for supplying the Dutch data; to the Office for National Statistics for supplying the data for England and Wales; and to Mark van Duijn (Faculty of Spatial Sciences, University of Groningen) for his support and guidance with the weighting procedure.

\section{Compliance with ethical standards}

Conflict of interest The authors declare that they have no conflict of interest.

Open Access This article is distributed under the terms of the Creative Commons Attribution 4.0 International License (http:// creativecommons.org/licenses/by/4.0/), which permits unrestricted use, distribution, and reproduction in any medium, provided you give appropriate credit to the original author(s) and the source, provide a link to the Creative Commons license, and indicate if changes were made. 


\section{References}

Abraído-Lanza AF, Dohrenwend BP, Ng-Mak DS, Turner JB (1999) The Latino mortality paradox: a test of the "salmon bias" and healthy migrant hypotheses. Am J Public Health 89:1543-1548

Arriaga E (1984) Measuring and explaining the change in life expectancies. Demography 21:83-96

Carnein M, Milewski N, Doblhammer G, Nusselder WJ (2014) Health inequalities of immigrants: patterns and determinants of health expectancies of Turkish migrants living in Germany. In: Doblhammer G (ed) Health among the elderly in Germany: new evidence on disease, disability and care need. Barbara Budrich, Leverkusen, pp 157-190

CBS (2016a) Definition of western background (in Dutch only). https://www.cbs.nl/nl-nl/faq/specifiek/wat-is-het-verschil-tusseneen-westerse-en-niet-westerse-allochtoon-. Accessed 18 Aug 2016

CBS (2016b) Information about POLS (in Dutch only). http://www. cbs.nl/nl-NL/menu/methoden/dataverzameling/permanentonderzoek-leefsituatie-pols-basisvragenlijst1.htm. Accessed 18 Aug 2016

CBS (2016c) Information about the Health Survey. http://www. cbs.nl/en-GB/menu/methoden/dataverzameling/health-surveyfrom2010-kob.htm. Accessed 18 Aug 2016

Chandola T, Jenkinson C (2000) Validating self-rated health in different ethnic groups. Ethnic Health (London) 5:151-159

Clair A, Reeves A, Loopstra R, McKee M, Dorling D, Stuckler D (2016) The impact of the housing crisis on self-reported health in Europe: multilevel longitudinal modelling of $27 \mathrm{EU}$ countries. Eur J Public Health 26:788-793

Croezen S, Burdorf A, Van Lenthe FJ (2016) Self-perceived health in older Europeans: does the choice of survey matter? Eur J Public Health 26:686-692

Fawcett J, Blakely T, Atkinson J (2002) Weighting the 81, 86, 91 and 96 census-mortality cohorts to adjust for linkage bias. NZCMS Technical Report No. 5. Department of Public Health, Wellington School of Medicine and Health Sciences, Wellington

Fouweather T, Gillies C, Wohland P, Van Oyen H, Nusselder W, Robine J-M, Cambois E, Jagger C, for the JA: EHLEIS team (2015) Comparison of socio-economic indicators explaining inequalities in healthy life years at age 50 in Europe: 2005 and 2010. Eur J Public Health 25:978-983

Gushulak B, Pace P, Weekers J (2010) Migration and health of migrants. In: Koller T (ed) Poverty and social exclusion in the WHO European region: health systems respond. WHO Regional Office for Europe, Copenhagen, pp 257-281

Harper S (2015) Addressing longevity, life expectancy and health life expectancy. Popul Ageing 8:223-226

Hu Y, Van Lenthe FJ, Borsboom GJ, Looman CWN, Bopp M, Burström B, Dzúrová D, Ekholm O, Klumbiene J, Lahelma E, Leinsalu M, Regidor E, Santana P, De Gelder R, Mackenbach JP (2016) Trends in socioeconomic inequalities in self-assessed health in 17 European countries between 1990 and 2010. J Epidemiol Community Health 70:644-652

International Organization for Migration (2009) Migrant health: better health for all in Europe. International Organization for Migration, Geneva

International Organization for Migration (2010) World migration report 2010. The future of migration: building capacities for change. International Organization for Migration, Geneva

Jagger C, Cox B, Le Roy S, and EHEMU (2006) Health expectancy calculation by the Sullivan method: a practical guide. EHEMU technical report

Jagger C, Gillies C, Moscone F, Cambois E, Van Oyen H, Nusselder W, Robine J-M, and the EHLEIS team (2008) Inequalities in healthy life years in the 25 countries of the European Union in 2005: a cross-national meta-regression analysis. Lancet 372:2124-2131

Jagger C, Weston C, Cambois E, Van Oyen H, Nusselder W, Doblhammer G, Rychtarikova J, Robine J-M, the EHLEIS team (2011) Inequalities in health expectancies at older ages in the European Union: findings from the survey of health and retirement in Europe (SHARE). J Epidemiol Community Health 65:1030-1035

Lanari D, Bussini O (2012) International migration and health inequalities in later life. Ageing Soc 32:935-962

Lanzieri G (2011) Fewer, older and multicultural?: projections of the EU populations by foreign/national background. Eurostat, Luxembourg

Lariscy JT, Hummer RA, Hayward MD (2015) Hispanic older adult mortality in the United States: new estimates and an assessment of factors shaping the Hispanic paradox. Demography 52:1-14

Markides KS, Eschbach K (2005) Aging, migration and mortality: current status of research on the Hispanic paradox. J Gerontol B-Psychol 60B(Special Issue II):68-75

Mladovsky P, Srivastava D, Cylus J, Karanikolos M, Evetovits T, Thomson S, McKee M (2012) Health policy responses to the financial crisis in Europe. Policy summary 5. Observatory on Health Systems and Policies. WHO Europe, Copenhagen

Nielsen SS, Krasnik A (2010) Poorer self-perceived health among migrants and ethnic minorities versus the majority population in Europe: a systematic review. Int J Public Health 55:357-371

Nørredam M, Krasnik A (2011) Migrants' access to health services. In: Rechel B, Mladovsky P, Devillé W, Rijks B, Petrova-Benedict R, McKee M (eds) Migration and health in the European Union. Open University Press, Berkshire, pp 67-80

Nusselder WJ, Looman CWN (2004) Decomposition of differences in health expectancy by cause. Demography 41:315-334

Preston S, Heuveline P, Guillot M (2000) Demography: measuring and modelling population processes. Blackwell Publishers, Oxford, pp 38-70

Razum O, Twardella D (2002) Time travel with Oliver Twist-Towards an explanation for a paradoxically low mortality among recent immigrants. Trop Med Int Health 7:4-10

Razum O, Zeeb H, Akgün HS, Yilmaz S (1998) Low overall mortality of Turkish residents in Germany persists and extends into a second generation: merely a healthy migrant effect? Trop Med Int Health 3:297-303

Rechel B, Mladovsky P, Devillé W, Rijks B, Petrova-Benedict R, McKee M (2011) Migration and health in the European Union: an introduction. In: Rechel B, Mladovsky P, Devillé W, Rijks B, Petrova-Benedict R, McKee M (eds) Migration and health in the European Union. Open University Press, Berkshire, pp 3-13

Reus-Pons M, Vandenheede H, Janssen F, Kibele EUB (2016) Differences in mortality between groups of older migrants and older non-migrants in Belgium, 2001-09. Eur J Public Health 26:992-1000

Riosmena F, Wong R, Palloni A (2013) Migration selection, protection, and acculturation in health: a binational perspective on older adults. Demography 50:1039-1064

Ronellenfitsch U, Razum O (2004) Deteriorating health satisfaction among immigrants from Eastern Europe to Germany. Int J Equity Health 3(4)

Seo S, Chung S, Shumway M (2014) How good is "very good"? Translation effect in the racial/ethnic variation in self-rated health status. Qual Life Res 23:593-600

Smith M, White C (2009) An investigation into the impact of question change on estimates of general health status and healthy life expectancy. Health Stat Q (ONS) 41:28-41

Solé-Auró A, Crimmins EM (2008) Health of immigrants in European countries. Int Migr Rev 42:861-876 
Sullivan DF (1971) A single index of mortality and morbidity. HSMHA Health Rep 86:347-354

Uitenbroek DG, Verhoeff AP (2002) Life expectancy and mortality differences between migrant groups living in Amsterdam, the Netherlands. Soc Sci Med 54:1379-1388
Wohland P, Rees P, Gillies C, Alvanides S, Matthews FE, O'Neill V, Jagger C (2014) Drivers of inequality in disability-free expectancy at birth and age 85 across space and time in Great Britain. J Epidemiol Community Health 68:826-833 